Reprod. Nutr. Dévelop., 1983, 23 (5), 847-855.

\title{
By-passing the sphincter of Oddi does not affect gallbladder emptying in the pig
}

\author{
R. JIMENEZ, Catherine JUSTE $\left({ }^{*}\right)$, T. CORRING $(*)$ \\ with the technical aid of Georgette FREDOU, F. COINTEPAS and A. VAN HECKE
}

Departamento Fisiologia Animal, Facultad de Biologia, Universidad de Salamanca, Salamanca, Spain.

(*) Laboratoire de Physiologie de la Nutrition, I.N.R.A., 78350 Jouy-en-Josas, France.

Summary. A study of the relationship between bile secretion and nutrition in the pig requires a complete and continuous collection of the bile and its reinfusion to the animal. In most of the studies performed in different species, bile has been directly reinfused into the duodenum, leading to the exclusion of the sphincter of Oddi from the biliary pathway. It has been postulated that such an exclusion could inhibit gallbladder emptying. The aim of the present work was to study postprandial gallbladder emptying in the pig, depending on the site of bile reinfusion, i.e. the duodenum or the lower bile duct. The gallbladder bile was coloured with indocyanine green (ICG) and marker secretion was recorded after a testmeal. The results showed that after meal intake, the gallbladder emptied over a similar period of time and according to similar kinetics, whatever the site of bile reinfusion.

\section{Introduction.}

Research on the physiology of bile secretion in relation to the diet ingested by the conscious pig eating normally requires the measurement of total amounts of bile and of its components : it is necessary to continuously collect the bile over experimental periods of several days in order to study the variation of its total quantity and of its components with the diet. Several surgical techniques using a biliary fistula have been developed to quantify bile secretion in pig (Laplace, 1976; Laplace and Ouaissi, 1977; Juste, Corring and Breant, 1979), dog (Nahrwold and Grossman, 1967) and monkey (Dowling et al., 1968). In order to keep the enterohepatic circulation intact and not to modify bile secretion (Dowling et al., 1968 ; Juste and Corring ; 1979), the bile was reinfused into the duodenum (Nahrwold and Grossman, 1967 ; Laplace, 1976 ; Laplace and Ouaissi, 1977 ; Juste, Corring and Breant, 1979), the lower bile duct (Laplace and Ouaissi, 1977) or the gastric antrum (Dowling et al., 1968). Direct reinfusion of bile into the duodenum or the gastric antrum by-passes the sphincter of Oddi and neglects 
the physiological function of this possible point for controlling bile flux (Watts and Dunphy, 1966) and gallbladder activity (Wyatt, 1967). According to Ashkin et al. (1978) and Laplace and Ouaissi (1977), exclusion of the sphincter of Oddi from the biliary pathway may perturb the physiology of bile secretion and even inhibit the functioning of the gallbladder (Laplace, 1976). Contrary to findings reported by Laplace and Ouaissi (1977), it was shown in a recent study in the pig (Juste, Corring and Le Coz, 1983b) that the daily bile flow was not affected by the site of bile reinfusion when bile was returned either at a constant rate or at a rate mimicking the pattern of the secretion. In contrast, daily, postprandial and interdigestive bile salt output was higher when bile was reinfused into the lower bile duct at a rate mimicking the secretion pattern of bile reinfused at that rate into the duodenum (Juste, Corring and Le Coz, 1983b). Therefore, because of its role in bile salt concentration and storage, the gallbladder might be suspected to be inert when bile is reinfused directly into the duodenum.

The present study was carried out to determine if reinfusing the collected bile into the duodenum, and thus by-passing the sphincter of Oddi in the biliary pathway, would inhibit gallbladder emptying in the pig. Comparative measurements were taken when the bile was re-introduced into the lower common bile duct, thus irrigating the sphincter of Oddi.

\section{Material and methods.}

Animals and diet. - Eight castrated male pigs of the Large White breed were used. After the pigs had been adapted to the experimental diet $125 \%$ lipids, $15.5 \%$ protein, $31.5 \%$ starch) for 8 days, they were divided into two groups of 4 each. The animals of group 1 (mean live weight before fistulation : $34.0 \pm 2.5 \mathrm{~kg}$ ) were fitted with a catheter in the common bile duct for bile collection and with another catheter in the lower bile duct for bile reinfusion. The pigs of group 2 (mean live weight before fistulation : $37.7 \pm 2.0 \mathrm{~kg}$ ) were fitted with a catheter in the common bile duct for bile collection and with a restituting catheter in the duodenum near the junction of the sphincter of Oddi. All the animals were also fitted with a catheter in the right external jugular.

The pigs were kept in metabolism-type cages throughout the experiment. During a postoperative 10 -day period, the intake level was gradually restored until it reached $1600 \mathrm{~g}$ of fresh matter per day distributed in 2 meals.

Biliary surgical procedure. - An extension of the method described previously was used (Juste, Corring and Breant, 1979). Under general anaesthesia and sterile conditions, the peritoneal cavity was opened and the common bile duct was identified distally to the entry of the cystic duct at about $2 \mathrm{~cm}$ from the duodenum. After the duct wall had been incised longitudinally for $0.5 \mathrm{~cm}$, a medical silastic catheter (outer $\varnothing=4.88 \mathrm{~mm}$; inner $\varnothing=2.64 \mathrm{~mm}$ ) was inserted and ligated into place. For group 1 animals, a second incision of $0.2 \mathrm{~cm}$ was made between the first one and the sphincter of Oddi ; a silastic tube of small diameter (outer $\varnothing=3.18 \mathrm{~mm}$; inner $\varnothing=1.57 \mathrm{~mm}$ ) was then gently inserted downwards without reaching the sphincter muscle and was ligated into 
place. For group 2 animals, a silastic catheter louter $\varnothing=3.18 \mathrm{~mm}$; inner $\varnothing=1.57 \mathrm{~mm}$ ) was inserted into the proximal duodenum, opposite to the opening of the common bile duct and ligated into place. For all animals both catheters were exteriorized through separate stab wounds in the right flank and the abdomen was closed in layers after a penicillin solution $(1,000,000 \mathrm{U})$ had been poured into the abdominal cavity. After surgery, antibiotics (penicillin : $1,000,000 \mathrm{U}$; streptomycin : $1.0 \mathrm{~g}$ ) were given daily by intramuscular injection for 3 days.

The bile began to drip as soon as the biliary fistula was inserted into the bile duct and restitution was carried out immediately after surgery. The catheters for bile collection and return were connected to an apparatus which returned the bile automatically; its functionning has been described by Juste, Corring and Le Coz (1983a). With this apparatus the secreted bile could be re-introduced immediately and its volume recorded at the same time that about $4 \%$ of the secreted bile was continuously withdrawn to be used as samples.

Experimental design. - In humans and in animals which have a gallbladder, the bile formed in the hepatic cells is secreted into the duodenum through the main hepatic duct. Some of the bile, called hepatic bile, is secreted directly into the intestine, while the rest passes through the cystic duct into the gallbladder. The gallbladder fills mainly during interdigestive periods (O'Brien et al., 1974) and empties after a meal has been ingested. Thus, if an exogenous bile marker, efficiently extracted by the liver and not recycled through the enterohepatic circulation, is intravenously perfused during an interdigestive period, a part of the marker will be stored in the gallbladder and the rest will be eliminated by hepatic bile. The stimulation of gallbladder emptying by feeding should then lead to the reappearance in the collected bile of the marker previously stored in the gallbladder.

Sixteen hours after the last meal, an intravenous injection of CCK-PZ (75 IU) was given to stimulate gallbladder emptying. Thirty minutes later, we began intravenously perfusing through the catheter in the jugular vein a solution of $360 \mathrm{ml}$ of $5 \%$ glucose containing $50 \mathrm{mg}$ of indocyanine green (ICG) $\left(^{*}\right)$ to mark the bile (Duane and Hanson, 1978). Preliminary assays led us to use $50 \mathrm{mg}$ of ICG in order to recover measurable amounts of the marker in the postprandial bile secretion. Perfusion at a rate of $2 \mathrm{ml} / \mathrm{min}$ lasted exactly $3 \mathrm{hrs}$. ICG, which soon appeared in the collected bile, was measured until its complete disappearance. The pig then received the experimental meal and the measurement of bile ICG was continued over a 4-hr postprandial period.

A total of 11 trials were carried out on the animals of group 1 (bile restitution into the lower common bile duct), while 9 were done on the animals of group 2 (bile restitution into the duodenum). There was an interval of at least $48 \mathrm{hrs}$ between the trials on each animal. We also carried out a control trial (perfusion of the glucose alone) on each animal. Finally, in 2 trials on two animals each in

${ }^{*}{ }^{*}$ SERVA. Feinbiochemica, Heidelberg (West Germany). 
groups 1 and 2, we continued to study bile secretion after the gallbladder had been removed.

Measurements of ICG in bile. - Bile samples were collected every hour from the beginning of perfusion until the experimental meal, and every 10 min afterwards.

The volume of secreted bile was measured directly by the apparatus. Bile ICG was spectrophotometrically measured at $805 \mathrm{~nm}$, using ICG-free bile taken from the same animal before perfusion as a blank. Optical densities were then converted into concentrations, using a standard curve plotted from known ICG concentrations in porcine bile. This curve was linear within the range of the ICG concentrations observed.

In order to study an eventual effect of ICG upon bile secretion, total bile acids were determined (Talalay, 1960) in bile collected over a 12-hrs period after initiation of ICG perfusion.

\section{Results.}

All results are reported as the mean \pm SEM. The statistical difference between two means was accepted as $P<0.05$.

ICG excretion in bile was studied until the marker had been completely eliminated in the secretion. Throughout the experimental period the results (table 1) showed similar recovery percentages (85.7 and $89.4 \%$, non-significant difference), whatever site was used to return the bile to the animal. When the quantities of ICG recovered during the periods before and after the experimental meal were expressed in relation to the total amount of the marker recovered, we found that an average of $99 \%$ was excreted in bile before the meal. The site of bile restitution did not affect the amount of ICG recovered during either of the two periods.

Elimination of ICG before the experimental meal. - Marker excretion in bile during the preprandial period, required $9.43 \pm 0.23 \mathrm{hrs}$ in group 1 pigs (common bile duct restitution) and $10.14 \pm 0.21 \mathrm{hrs}$ in group 2 animals (duodenal restitution).

TABLE 1

Bile ICG recovery after the initiation of perfusion.

\begin{tabular}{|c|c|c|}
\hline & $\begin{array}{l}\text { Common bile duct } \\
\text { restitution } \\
\text { (group 1) }\end{array}$ & $\begin{array}{l}\text { Duodenal } \\
\text { restitution } \\
\text { (group 2) }\end{array}$ \\
\hline 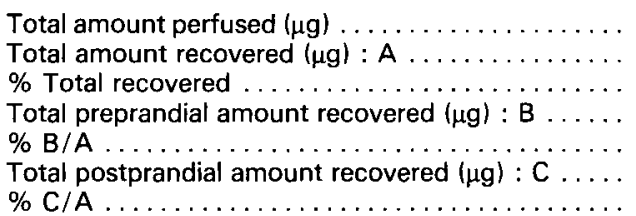 & $\begin{aligned} & 47663 \pm 367(1) \\
& 40900 \pm 1155 \\
& 85.71 \pm 1.87 \\
& 40578 \pm 1199 \\
& 99.19 \pm 0.36 \\
& 321 \pm 140 \\
& 1.13 \pm 0.35\end{aligned}$ & $\begin{array}{rr}\text { NS } & 48528 \pm 186 \\
\text { NS } & 43360 \pm 476 \\
89.35 & \pm 0.88 \\
83 & 42826 \pm 492 \\
\text { NS } & \pm 8.76 \pm 0.30 \\
& 98.73 \pm 131 \\
\text { NS } & 534 \pm 1.24 \pm 0.30\end{array}$ \\
\hline
\end{tabular}

(1) Mean \pm SEM. 
When the quantities of biliary ICG, expressed as a percentage of the total amount of marker preprandially recovered, were plotted against time, the kinetics of ICG elimination were found to be very similar for both sites of bile restitution (fig. 1). Secondly, maximal excretion of the marker was observed between the 2nd and 3rd hours after perfusion began. $70 \%$ of the total preprandial ICG recovered was eliminated during perfusion in all the animals.

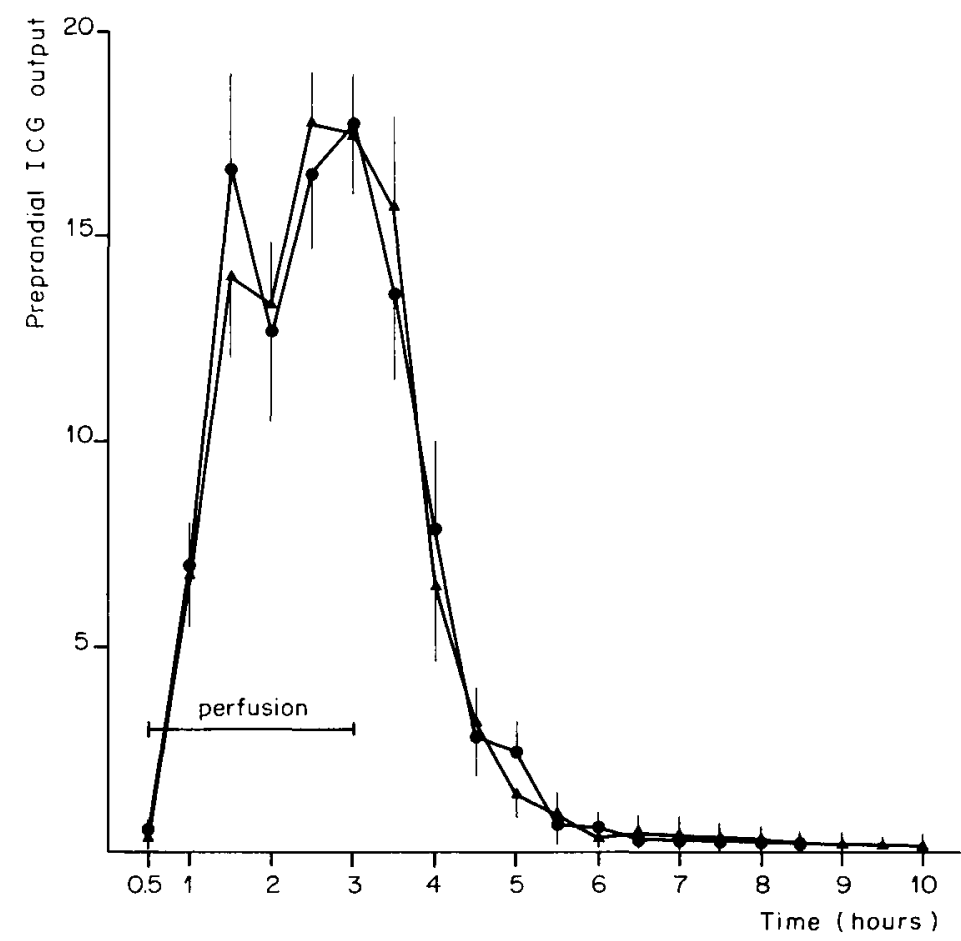

FIG. 1. - Preprandial ICG output expressed in relation to the time after perfusion began and in percentage of the total amount of preprandial marker recovered. $\mathbf{\Delta} \mathbf{\Delta}$ : restitution of bile into the duodenum ; - : restitution of bile into the lower common bile duct.

Elimination of ICG after the experimental meal. - The first result concerns the appearance of the marker in the collected postprandial bile of all the animals. No trace of ICG was detected during this postprandial period in pigs without a gallbladder.

ICG began to appear during the first $10 \mathrm{~min}$ after the pigs had begun ingesting the meal ; the marker was eliminated in $80 \pm 8 \mathrm{~min}$ when the bile was re-introduced before the sphincter of Oddi and in $117 \pm 20 \mathrm{~min}$ when it was reintroduced directly into the duodenum (non-significant difference).

When the fraction of non-eliminated ICG (ICG remaining in the gallbladder), expressed as a percentage of the total amount of marker postprandially recovered. was plotted against time, it was found that marker elimination in response to the experimental meal did not depend on the site of bile restitution (fig. 2). Moreover, these curves were log-linear during at least the first 50 to 60 postprandial minutes. 


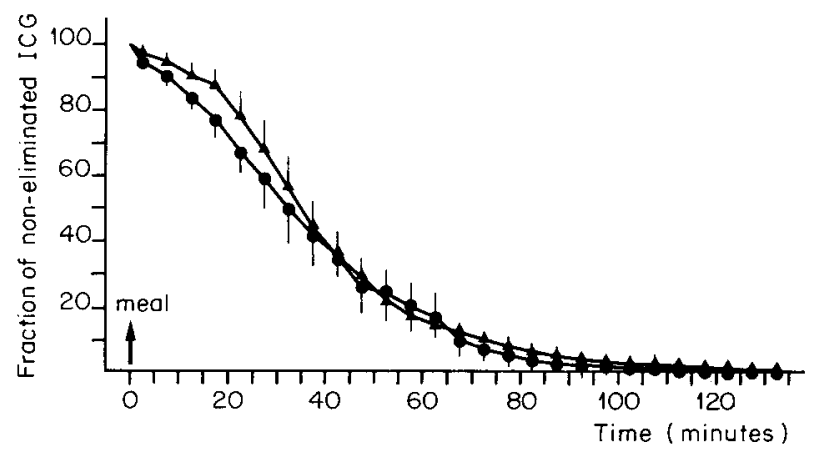

FIG. 2. - Fraction of non-eliminated ICG after meal consumption, expressed in percentage of the amount of the marker recovered postprandially in relation to time. $\mathbf{\Lambda} \mathbf{\Lambda}:$ restitution of bile into the duodenum : - restitution of bile into the lower common bile duct.

The flow of ICG secretion seemed maximal in both groups of pigs at the same time after the meal had begun (group $1: 31.00 \pm 3.80 \mathrm{~min}$; group 2 : $29.17 \pm 1.67 \mathrm{~min})$. This flow was $5.54 \pm 2.17 \mu \mathrm{g} / \mathrm{min}$ when the bile was reintroduced into the lower common bile duct and $14.67 \pm 5.14 \mu \mathrm{g} / \mathrm{min}$ when it was returned directly into the duodenum (non-significant difference).

Effect of ICG on bile secretion. - Whatever the site of bile restitution, ICG infusion did not affect the volume of bile secreted over a 12-hr period after perfusion began (table 2). However, the quantity of bile acids secreted over the same period tended to decrease in both groups of pigs. These results should be accepted with caution due to the small number of control trials (glucose serum only perfused).

TABLE 2

Volume of bile and total bile acids secreted over a 12-hr period after the initiation of perfusion.

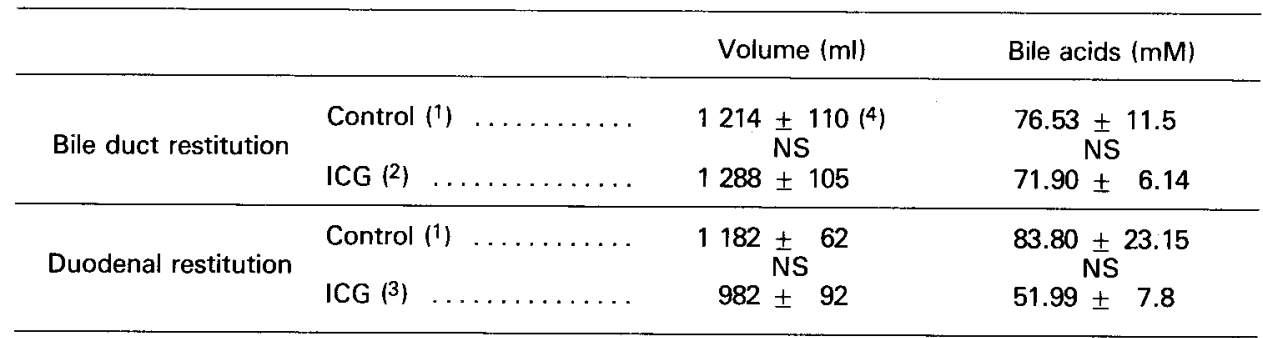

(1) Glucose serum perfusion : 4 trials ; (2) ICG perfusion : 11 trials ; (3) ICG perfusion : 9 trials ; (4) Mean \pm SEM.

\section{Discussion.}

We used indocyanine green (ICG) to mark the gallbladder contents. This dye, an excellent marker for studying hepatic function, has been used in many physico-chemical and physiological studies (Wheeler, Cranston and Meltzer, 1958 ; Cherrick et al., 1960 ; Gathje, Steuer and Nicholes, 1970 ; Duane and 
Hanson, 1978) which show that the marker is not recycled through the enterohepatic circulation and is almost exclusively extracted by the liver.

ICG has an anticholeretic effect in the rat, rabbit and dog (Klaassen and Plaa, 1969). In the rat (Horak, Grabner and Paumgartner, 1973) this effect appears at marker doses of $3 \mu \mathrm{mol} / 100 \mathrm{~g}$ of live weight, exceeding the capacity of hepatic secretion to transport it. In the study reported, bile secretion of the pig was not depressed by ICG perfusion, when an ICG dose of $0.2 \mu \mathrm{mol} / 100 \mathrm{~g}$ of live weight was perfused.

The percentage of ICG recovered at the end of the trial did not significantly differ with the bile restitution site, and the values obtained $185.7 \%$ when bile was re-introduced before the sphincter of Oddi and $89.4 \%$ when it was introduced into the duodenum) were similar to those found in dog (Ketterer, Wiegand and Rapaport, 1960) and in humans (Cherrick et al., 1960) after marker injection. However, these values are slightly less than the $95 \%$ recoveries obtained $6 \mathrm{hrs}$ after ICG injection in the rat, and the 91.1 and $99.4 \%$ recoveries found $8 \mathrm{hrs}$ after maker injection in the dog (Hunton, Bollman and Hoffman, 1960). In the above mentioned works as in the present study, it is probable that the method of bile ICG measurement was not sensitive enough to detect very small amounts of the marker.

Most of the perfused ICG (99\%) was excreted before the meal was ingested over a similar length of time and according to similar kinetics, whatever the site of bile restitution. Maximal ICG concentration in the bile was observed between the 2nd and 3rd hours after perfusion began. The maximal peak of ICG concentration was obtained $120 \mathrm{~min}$ after its injection in humans (Cherrick et al., 1960), 60 to 90 min (Hunton, Bollman and Hoffman, 1960) and 2 to 3 hrs $\sqrt{K e t t e r e r, ~ W i e g a n d ~}$ and Rapaport, 1960) after its injection in the dog.

Ingestion of a meal resulted in a bile secretion containing fair amounts of ICG. The absence of the marker in the postprandial bile of the same pigs after cholecystectomy, confirmed that the marker bile in response to meal in the intact animals, did originate in the gallbladder. This result emphasizes that in our experimental conditions, by-passing the sphincter of Oddi in the biliary pathway did not inhibit the emptying of the gallbladder. This finding agrees well with data showing that sphincteroplasty in dogs did not affect the gallbladder motor response to stimulation by cholecystokinin (Cohn et al., 1979). On the contrary, Laplace (1976) and Laplace and Ouaissi (1977) assumed that exclusion of the sphincter of Oddi from the biliary pathway led to inhibition of gallbladder emptying. However their assumption was based on indirect measurement such as periprandial observations of bile flow in pigs whose sphincter of Oddi was bypassed or irrigated.

The present study on the pig did not permit us to determine the role of the sphincter of Oddi in the physiology of bile secretion, a role judged to be essential in humans (Ashkin et al., 1978); neither were we able to describe the normal functioning of the gallbladder, whatever the site used to return the bile to the animal. The kinetics of postprandial excretion of bile ICG, which are remarkably similar whether the bile is re-introduced before the sphincter of Oddi or directly into the duodenum, nevertheless resemble those described in humans (Duane and 
Hanson, 1978) in a study which included no fistulation of the biliary system. In the pig, we found the typical profile of log-linear bile secretion described in humans during a postprandial period of 40 to $50 \mathrm{~min}$.

\section{Conclusion.}

We conclude that gallbladder emptying is not inhibited when the sphincter of Oddi is not irrigated by bile secretion. Among other things, this may be due to an effect of the CCK-PZ released by the presence of the products of protein and lipid digestion (Malagelada et al., 1973) or to changes of gastroduodenal motility (Peeters, Vantrappen and Janssens, 1980 ; Itoh and Takahashi, 1981) or to an association of these two phenomena.

Reçu en novembre 1982. Accepté en avril 1983.

Résumé. Evacuation de la vésicule biliaire après dérivation du sphincter d'Oddi du trajet biliaire chez le porc fistulé.

L'étude de la sécrétion biliaire en relation avec l'alimentation nécessite la collecte intégrale et continue de la bile ainsi que sa restitution à l'animal. Dans la plupart des travaux réalisés chez différentes espèces, la bile a été réinfusée directement dans le duodénum, ce qui conduit à l'exclusion du sphincter d'Oddi du trajet biliaire. L'hypothèse d'une inhibition de l'évacuation de la vésicule biliaire dans ce cas de restitution a été avancée. Le but du présent travail est d'étudier l'évacuation de la vésicule biliaire chez le porc, en relation avec le site de réinfusion de la bile : duodénum ou bas-cholédoque. Les cinétiques d'évacuation de bile vésiculaire, préalablement colorée avec du vert d'indocyanine (ICG) sont enregistrées sur porcs fistulés en réponse à un repas test. Les résultats montrent que, quel que soit le site de réintroduction de la bile, la consommation du repas provoque une évacuation vésiculaire sur une période de temps et selon une cinétique identique.

\section{References}

ASHKIN J. R., LYON D. T., SHULL S. D., WAGNER C. I., SOLOWAY R. D., 1978. Factors affecting delivery of bile to the duodenum in man. Gastroenterology, 74, 560-565.

CHERRICK G. R., STEIN S. W., LEEVY C. M., DAVIDSON C. S., 1960. Indocyanine green : observations on its physical properties, plasma decay, and hepatic extraction. J. clin. Invest., 39, 592-600.

COHN M. S., SCHWARTZ S. I., FALOON W. W., ADAMS J. T., 1979. Effect of sphincteroplasty on gallbladder function and bile composition. Ann. Surg., 189, 317-321.

DOWLING R. H., MACK E., PICOTT J., BERGER J., SMALL D. M., 1968. Experimental model for the study of the enterohepatic circulation of bile in rhesus monkeys. J. Lab. clin. Med., 72, 169-176.

DUANE W. C., HANSON K. C., 1978. Role of gallbladder emptying and small bowel transit in regulation of bile acid pool size in man. J. Lab. clin. Med., 92, 858-872.

GATHJE J., STEUER R. R., NICHOLES K. R. K., 1970. Stability studies on indocyanine green dye. J. appl. Physiol., 29, 181-185.

HORAK W., GRABNER G., PAUMGARTNER G., 1973. Inhibition of bile salt-independent bile formation by indocyanine green. Gastroenterology, 64, 1005-1012.

HUNTON D. B., BOLLMAN J. L., HOFFMAN H. N., 1960. Studies of hepatic function with indocyanine green. Gastroenterologv, 39, 713-724. 
ITOH Z., TAKAHASHI I., 1981. Periodic contractions of the canine gallbladder during the interdigestive state. Am. J. Physiol., 240 (Gastrointest. Liver Physiol.), 3, G183-G189.

JUSTE C., CORRING T., 1979. Effet d'une interruption et de restitutions partielles du recyclage entérohépatique sur le niveau de l'excrétion biliaire chez le porc. Ann. Biol. anim. Bioch. Biophys., 19, 405-412.

JUSTE C., CORRING T., BREANT Ph., 1979. Excrétion biliaire chez le porc : niveau et réponse au repas. Ann. Biol. anim. Bioch. Biophys., 19, 79-90.

JUSTE C., CORRING T., LE COZ Y., 1983a. Bile restitution procedures for studying bile secretion in the fistulated pig. Lab. anim. Sci, 33, 199-202.

JUSTE C., CORRING T., LE COZ Y., 1983b. Bile secretion in the fistulated pig: effect of the method used for bile reinfusion. Reprod. Nutr. Dévelop, 23, 765-773.

KETTERER S. G., WIEGAND B. D., RAPAPORT E., 1960. Hepatic uptake and biliary excretion of indocyanine green and its use in estimation of hepatic blood flow in dogs. Am. J. Physiol., 199, 481-484.

KLAASSEN C. D., PLAA G. L., 1969. Plasma disappearance and biliary excretion of indocyanine green in rats, rabbits and dogs. Toxicol. appl. Pharmacol., 15, 374-384.

LAPLACE J. P., 1976. L'excrétion biliaire chez le Porc. 2. - Electromyographie et dynamique de l'excrétion de bile. Rec. Méd. vét,, 152, 401-411.

LAPLACE J. P., OUAISSI M. A., 1977. L'excrétion biliaire chez le Porc. Influence des repas et rôle éventuel de récepteurs oddiens dans le contrôle du débit cholédocien. Ann. Zootech., 26, 595-613.

MALAGELADA J. R., GO V. L. W., DIMAGNO E. P., SUMMERSKILL W. H. J., 1973. Interactions between intraluminal bile acids and digestive products on pancreatic and gallbladder function. J. clin. Invest., 52, 2160-2165.

NAHRWOLD D. L., GROSSMAN M. I., 1967. Secretion of bile in response to food with and without bile in the intestine. Gastroenterology, 53, 11-17.

O'BRIEN J. J., SHAFFER E. A., WILLIAMS L. F., SMALL D. M., LYNN J., WITTENBERG J., 1974. A physiological model to study gallbladder function in primates. Gastroenterology, 67. 119-125.

PEETERS T. L., VANTRAPPEN G., JANSSENS J., 1980. Bile acid output and the interdigestive migrating motor complex in normals and in cholecystectomy patients. Gastroenterology, 79, 678-681.

TALALAY P., 1960. Enzymatic analysis of steroid hormones. Methods Biochem. Anal., 8, 119-143.

WATTS J. K. Mc, DUNPHY J. E., 1966. The role of the common bile duct in biliary dynamics. Surg. Gynecol. Obstet., 122, 1207-1218.

WHEELER H. O., CRANSTON W. I., MELTZER J. I., 1958 . Hepatic uptake and biliary excretion of indocyanine green in the dog. Proc. Soc. exp. Biol. Med., 99, 11-14.

WYATT A. P., 1967. The relationship of the sphincter of Oddi to the stomach, duodenum and gallbladder. J. Physiol. London, 193, 225-243. 